Bangladesh J. Bot. 47(4): 927-935, 2018 (December)

\title{
TRADITIONAL AGROFORESTRY SYSTEMS AND BIODIVERSITY CONSERVATION
}

\author{
Doddabasawa* $^{* 1}$, BM ChitTapur ${ }^{2}$ and M Mahadeva Murthy \\ Department of Forestry and Environmental Science, University of Agricultural Sciences, \\ GKVK, Bangaluru-65, India
}

Keywords: Agroforestry, Biodiversity conservation, Threatened species, Species richness, Tree density

\begin{abstract}
A survey was made to assess the biodiversity in traditional based agroforestry systems under rainfed agroecological situation in north eastern part of Karnataka, India and 27 tree species belonging to 15 families were recorded. Fabaceae was found to be the predominant family accounting for 11 species followed by Meliaceae and Rutaceae with 2 species each while other families had one species each. However, higher tree density per hectare was observed in Azadiractha indica (19.71) belonging to Meliaceae. Among the 27 species Sandal wood and Stain wood were listed in IUCN red list as threatened species. The highest number of families and species were observed in Koppal (11 and 20, respectively) closely followed by Yadgir district (10 and 20, respectively) while lower number of plant families and species were observed in Bidar district (6 and 11, respectively). Most of the species were used for timber (55.56\%) purpose followed by fodder $(48.15 \%)$, while 7.1 per cent were maintained for religious reasons.
\end{abstract}

\section{Introduction}

Biodiversity conservation is not confined to the natural ecosystems like forest and wood lands but also extended to farm lands as well. The role of farm areas and the farming community which have promoted the biodiversity in the subsistence agricultural production systems was ignored in the past in conserving biodiversity (Vodouhe et al. 2011). Therefore, different components of agricultural biodiversity and their role in sustainable production, livelihood security and protection of ecosystem are given great importance in these days. Traditionally, farmers used to maintain the diversity within and between the crops to meet their diversified needs like food, fodder, fuel wood and also as source of additional income generation besides optimum use of land and resources (Atta-Krah et al. 2004). Agroforestry is as old as agriculture itself, which contributes to agricultural biodiversity with increased number of trees and shrubs on the farm. That apart, perennial component on the farm enhances other agricultural diversities like predators, pollinators, soil microbes etc. (Chittapur et al. 2017). In the recent days the agroforestry systems have been widely promoted in the tropics as natural resource management strategy that sustains the agricultural production with conservation of soil and water and enhances the carbon sequestration and biodiversity (Schroth et al. 2004, Nair 2011). Further quantum of research reveals that the traditional agroforestry systems contribute the conservation of biodiversity thorough in situ conservation of tree species on farms, reduction of pressure on forest and provides suitable habitat for number of plant and animal species on farm land (Quinsavi et al. 2005, Acharya 2006, McNeely and Schroth 2006, Quinsavi and Sokpon 2008).

Broadly, there are three categories of agroforestry systems found on farm lands: first one is the age old traditional agroforestry systems, second one consisting of modules developed through the formal scientific research, and the third one is borne out of the research but later modified

\footnotetext{
*Author for correspondence: <dkpati12020@gmail.com>. ${ }^{1}$ Department of Farm Forestry, College of Agriculture, Bheemarayanagudi, Yadgir District, Karnataka, India. ${ }^{2}$ Chief Scientific Officer, University of Agricultural Sciences, Raichur 584 102, Karnataka, India.
} 
further evolved and adopted by the farmer himself (Nair 1985). The second and third categories of agroforestry systems are oriented towards integration of only a few tree species which are of economical importance, fast growing, input responsive and high yielding. However, the traditional system of agroforestry maintains higher diversity. Whereas, the composition and pattern of these traditional based agroforestry land use system are location specific, performance biased, and preference of the farmer and culture of the countries (Nair et al. 2008). However, it is important to mention that despite significance of trees in biodiversity and ecological security, due to intensification of grain-based agriculture for short term economic reasons, the traditional agroforestry systems are disappearing from the landscape (Nerlich et al. 2013). Therefore, the present study was undertaken to take stock of present status of genetic and species level diversity in traditional based agroforestry systems in north eastern part of Karnataka.

\section{Materials and Methods}

A survey was made in north eastern part of Karnataka (Comprising north eastern transitional zone, north eastern dry zone and northern dry zone of the state) to assess the tree diversity in the traditional based agroforestry systems under rainfed agroecological situation (Fig. 1). The study area lies within the geographical region of north maiden; spreading between $14^{0} 60^{\prime}$ to $18^{0} 30^{\prime}$ Northern latitude and $75^{\circ} 60$, to $77^{\circ} 70^{\prime}$ Eastern longitude. This region comprises of six districts, namely Bidar, Ballari, Kalaburagi, Koppal, Raichur and Yadgir.The background information of the study area was collected by visiting District statistical office and interacting with staff of line departments, while weather data was collected from the representative meteorological units located in the study area. The average rainfall ranges between 600 and $900 \mathrm{~mm}$ with an elevation ranging from $350-650 \mathrm{~m}$. The soils of this region are deep to very deep black soils with medium deep black soils in major areas, while sandy loam and light structured soils are also found in some pockets. The major crops grown are pigeon pea, greengram, Bengalgram, groundnut, soybean, sunflower, safflower, sorghum, and pearlmillet, and cotton, sugarcane and paddy under irrigation.

Multistage purposive randomized sampling technique was used to select the samples for the study by selecting districts as unit (6 districts) and in each district two taluks were identified, in each taluk one village was identified and in each village 6 respondents were selected randomly among the list of the farmers who are already practicing agroforestry systems, and in all, the total sample size was comprised of 72 farmers. The information on the existing traditional based agroforestry systems, species richness, family richness, diversity and density were recorded by visiting the field physically and interviewing the farmers/holders with structured questionnaire prepared for the study.

The data on species and family richness were obtained by aggregating number of species present and expressed as total number of species per agroforestry systems, per district and per category of farmers. The species density was calculated per hectare scale which was calculated by aggregating total number of species found in different districts divided by the total farmers in the districts and expressed as mean number per hectare. Similarly, the tree density was calculated by counting total number of trees divided by the number of farmers and expressed as mean number per hectare. The dominance of the tree species on farm land was calculated by taking the relative density of the species which was calculated by dividing the total number of individual species to the overall total of all the species. The data on the species diversity were also subjected to Shannon and Simpson's diversity index analyses which was calculated by using Shannon's index

$$
\mathrm{H}^{\prime}=\sum_{i=1}^{n} \mathbf{P i}^{\mathrm{ln}} \mathrm{P}_{\mathrm{i}} \text { and Simpson index } \lambda=\sum_{i=1}^{n} P i^{\boldsymbol{z}}
$$


where ' $n$ ' is the total number of species and ' $p$ ' is the relative abundance of $i^{\text {th }}$ species (Christine and Nestor 2008). The data collected were analyzed for descriptive statistics and one way ANOVA at a significance level of 0.05 and further, to know the difference between the means post hoc test was performed using Duncan test at significance level of 0.05 by using SPSS (Statistical Package for Social Science).

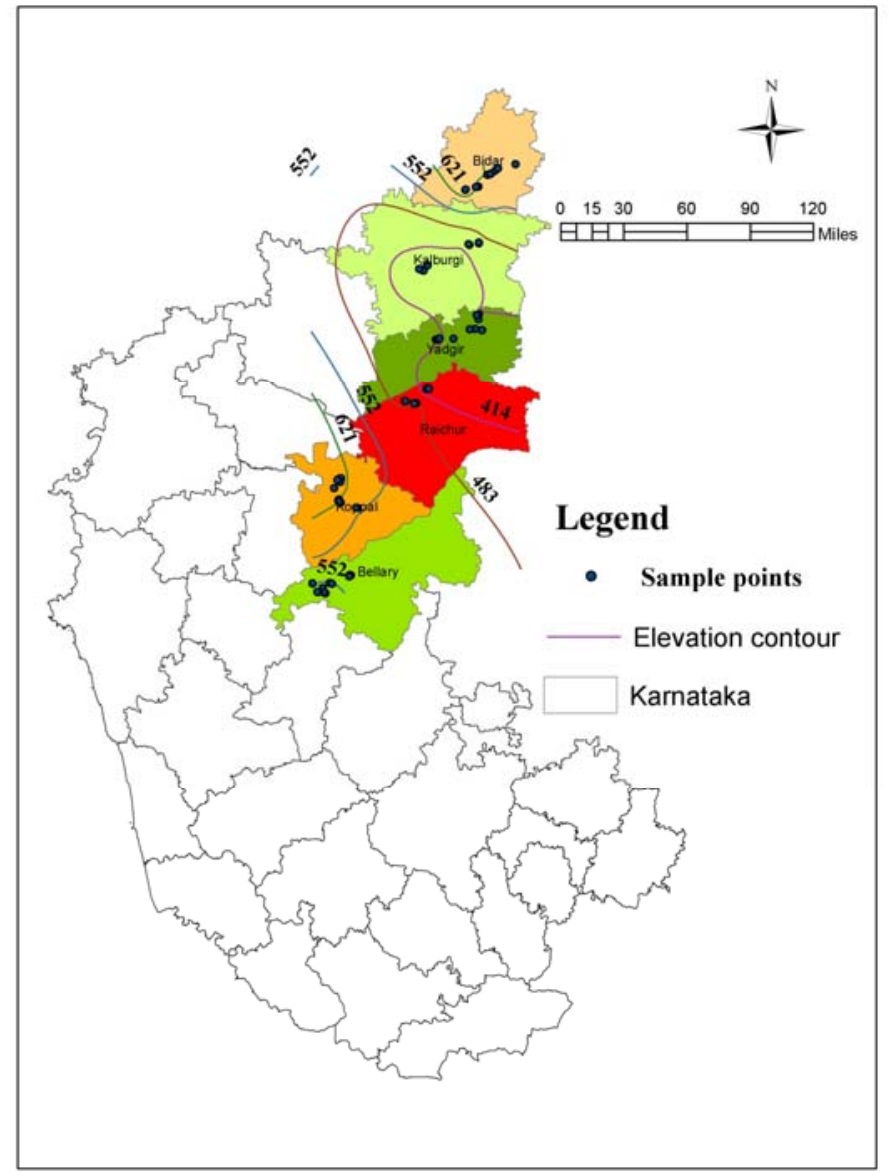

Fig. 1. Indicating the study area under rainfed ecosystem.

\section{Results and Discussion}

Generally the farmers retain the trees on the farm mainly on the bund and boundary of the farm and sometimes scattered way in the infield for their livelihood goals of income generation, risk management strategy, household food security and optimal utilization of land, labor and capital (Chittapur and Patil 2017). However, the type and composition of tree species, distribution and extent varying with the topography, biophysical attributes and socioeconomic condition of the resource managers (Dhakal et al. 2012). In the study area bund planting, boundary planting and scattered planting were the major traditional based agroforestry systems practiced by the farmers and as many as 27 tree species belonging to 15 families were recorded. Out of these, 92.59 per cent of the species are indigenous to the area. Among the families, Fabaceae was found to be 
dominant with 11 species followed by Meliaceae and Rutaceae with 2 species in each and the rest of the families contributed single species each. The study indicated that the traditional agroforestry systems composed more of indigenous species. It might be due to the age old tradition of using the indigenous species by the farmers. Who knew their survivability the economic and ecological value of these indigenous tree species. The results are in line with the findings of Vodouhe et al. (2011) who reported 21 species belonging to 14 families in traditional agroforestry systems in Benin (West Africa) and further they reported that 85 per cent of the total 21 tree species were indigenous. They opined that the farmers conserved higher indigenous tree species of multiple uses.

Among the 27 species, Santalum album and Chloroxylon swietenia (Rutaceae) were listed IUCN Red list as threatened species and Limonia acidissima (Rutaceae) as endemic species (Table 1), because these species are over exploited for their great economic value and of slow growth. This emphasizes that Santalaceae and Rutaceae need attention for conservation. The results are in concurrence with the results reported by Luke et al. (2011) who reported that out of 24 species 23 are vulunerable and one species as endangered according IUCN 2006 criteria.

Further, the mean density of trees recorded was 28.57 per ha, while Azadiractha indica belongs to Meliaceae with 19.71 trees per ha predominated the total species. It is attributed to its multiple utility as timber, fodder, fertilizer, pesticidal and medicinal value and also because of its adaptability to semiarid ecological conditions. Apart from Azadiractha indica, other most frequent species in the region were, Acacia nilotica and Ziziphus mauritiana (Table 1).

Species composition also varied among the districts though Azadirachta indica was the prominent species in all the districts (Table 2). The order was A. indica, Acacia nilotica and Ziziphus mauritiana in Bidar and Kalaburagi districts, A. indica, Tamarindus indica and Acacia nilotica in Yadagir district, A. indica, A. nilotica, Prosopis cineraria and Z. mauritiana in Raichur district, A. indica, A. nilotica and Prosopis cineraria in Ballari, while A. indica, Acacia ferruginea and Cassia fistula dominated the farm ecosystem in Koppal. This variation could be attributed to suitability of ecological conditions and local preference for their multiple uses. The results are in line with Vodouhe et al. (2011) who in Benin (West Africa) observed Vitellaria paradoxa (90\%), Parkia biglobosa (75\%) and Lannea microcarpa (29\%) as the three most frequented species on the farm land for their uses as timber wood, fuel, fodder and also other benefits like shade and soil fertility improvement.

The mean number of species per hectare and mean number of trees per hectare were 5.35 and 28.57 , respectively, however, a lot of variation with respect to the number of families, number of species, mean species density and mean number of trees per hectare was observed between the districts. Maximum number of families and species were recorded in Koppal district (11and 20, respectively) followed by Yadgir district (10 and 20, respectively) and the lowest was observed in Bidar district (6 and 11, respectively). Further, the mean species density per hectare was significantly higher in Yadgir district (6.25) followed by Koppal (6.17) and least was with Ballari district (3.67). Whereas, non-significant differences were observed among the districts for tree density per hectare (Table 3). However, higher Shannon index was recorded $t$ in Yadgir district (1.60) followed by the Koppal (1.43) and lowest was with Ballari district (0.93). Thus, the diversity was higher in Yadagir and Koppal disticts while it was lower in Ballari district (Table 3). This might be partly due to rainfall distribution as Yadgir and Koppal receive relatively more rainfall. That apart, the sampling units of Koppal and Yadgir districts were located in higher elevations. Bucagu et al. (2013) also attributed higher tree diversity in agroforestry systems of two ecological situations to higher elevation which with reduced temperature and congenial environmental conditions favours tree growth. Further, they also attributed to biophysical and socioeconomic condition of the region. 


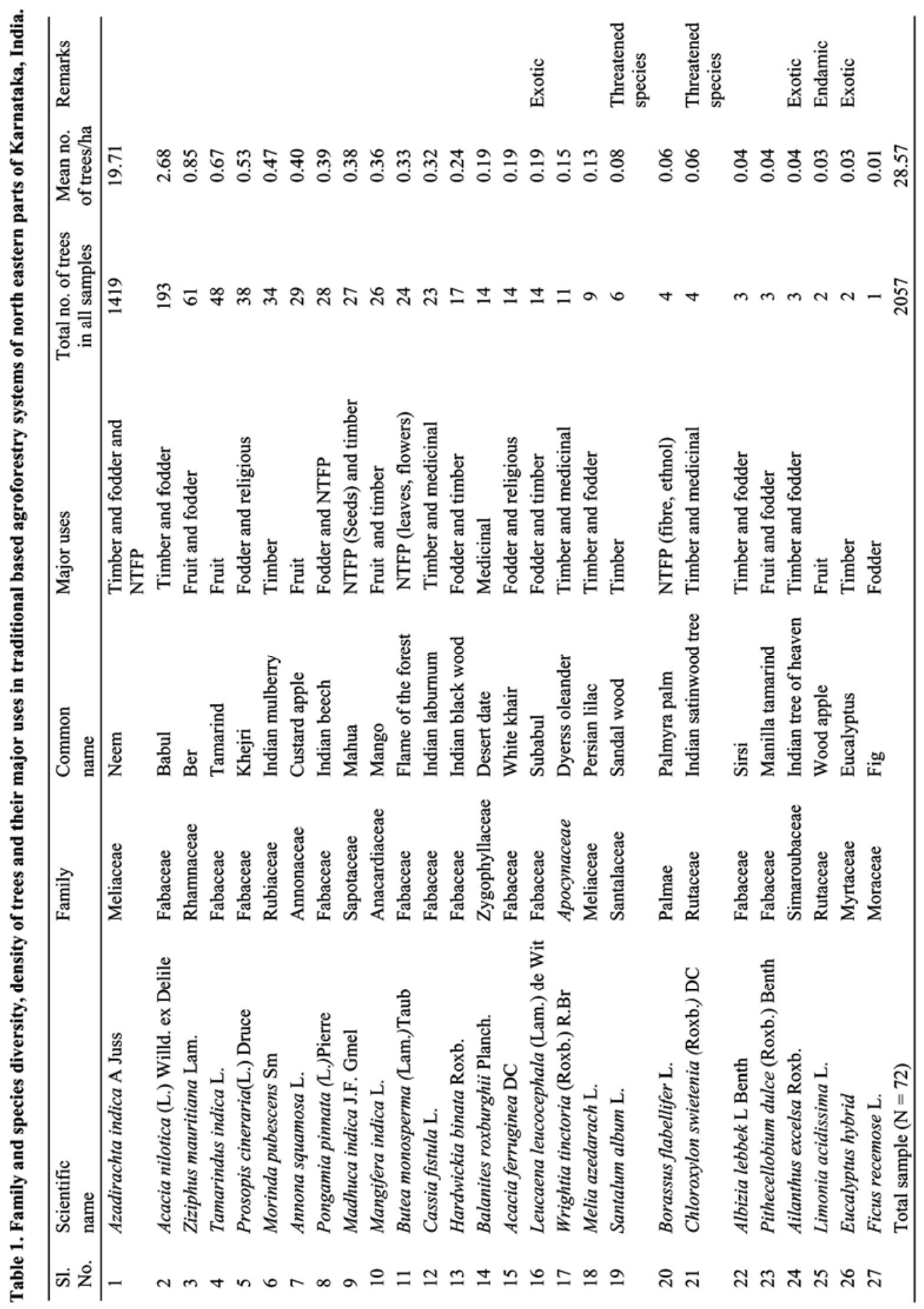




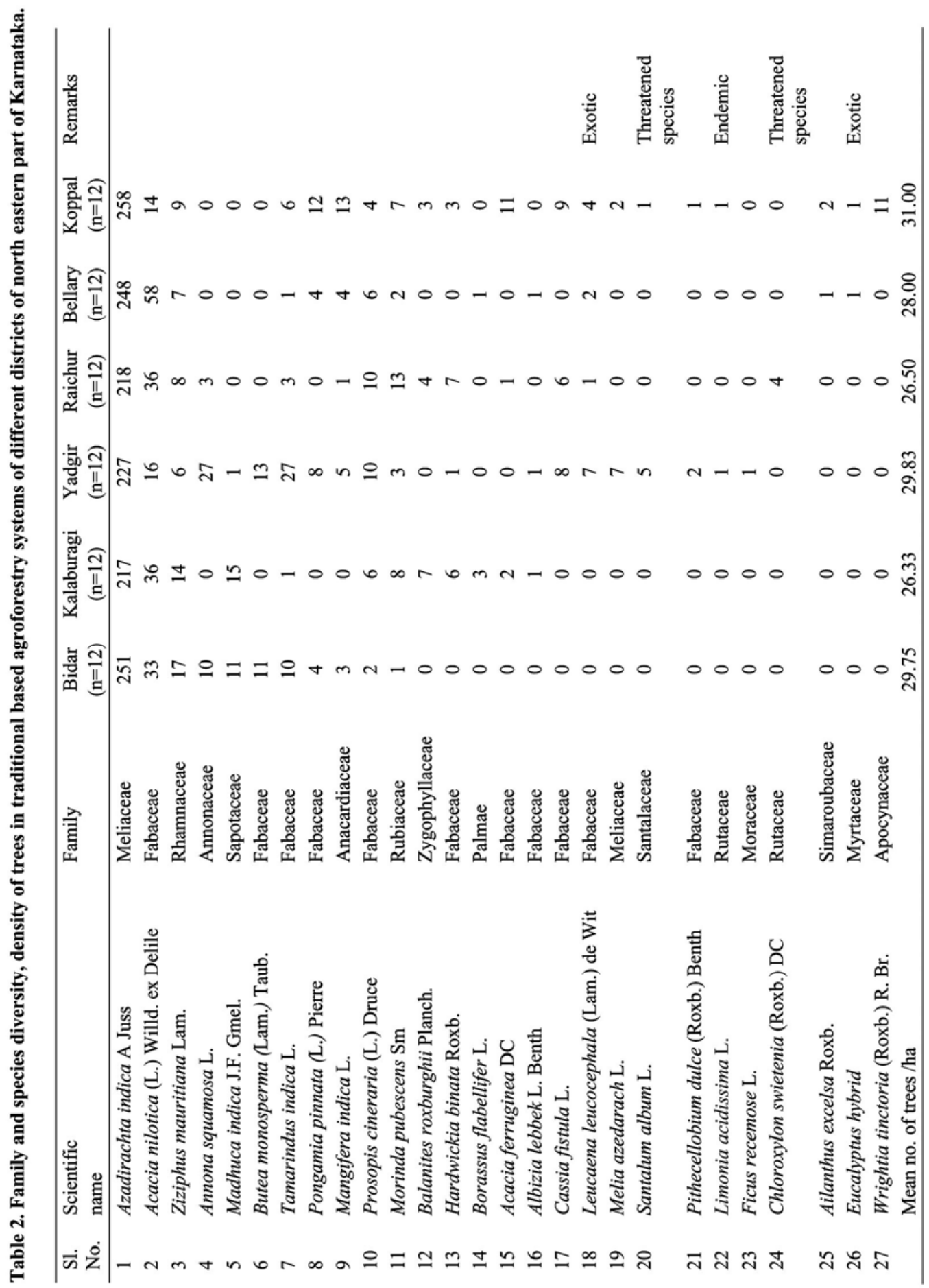


Table 3. Species and family richness, mean species and tree density in traditional based agroforestry systems in different districts of north eastern part of Karnataka.

\begin{tabular}{|c|c|c|c|c|c|c|}
\hline Districts & $\begin{array}{c}\text { Family } \\
\text { richness } \\
\text { (Total number) }\end{array}$ & $\begin{array}{l}\text { Species richness } \\
\text { (Total number) }\end{array}$ & $\begin{array}{l}\text { Species density } \\
\text { (Mean species } \\
\text { density /ha) }\end{array}$ & $\begin{array}{l}\text { Tree density } \\
\text { (Mean no. of } \\
\text { trees/ha) }\end{array}$ & $\mathrm{H}$ & $\lambda$ \\
\hline Bidar $(n=12)$ & 6 & 11 & $\begin{array}{l}5.25^{b} \\
( \pm 0.75)\end{array}$ & $\begin{array}{l}29.75 \\
( \pm 8.71)\end{array}$ & $\begin{array}{l}1.05^{\mathrm{b}} \\
( \pm 0.25)\end{array}$ & $\begin{array}{l}0.50^{\mathrm{ab}} \\
( \pm 0.13)\end{array}$ \\
\hline Kalaburgi $(\mathrm{n}=12)$ & 7 & 12 & $\begin{array}{l}5.25^{b} \\
( \pm 0.62)\end{array}$ & $\begin{array}{l}26.33 \\
( \pm 8.77)\end{array}$ & $\begin{array}{l}1.06^{\mathrm{b}} \\
( \pm 0.27)\end{array}$ & $\begin{array}{l}0.49^{\mathrm{a}} \\
( \pm 0.14)\end{array}$ \\
\hline Yadgir $(n=12)$ & 10 & 20 & $\begin{array}{l}6.25^{\mathrm{b}} \\
( \pm 2.09)\end{array}$ & $\begin{array}{l}27.00 \\
( \pm 11.63)\end{array}$ & $\begin{array}{l}1.21^{\mathrm{b}} \\
( \pm 0.30)\end{array}$ & $\begin{array}{l}0.44^{\mathrm{a}} \\
( \pm 0.12)\end{array}$ \\
\hline Raichur $(\mathrm{n}=12)$ & 8 & 14 & $\begin{array}{l}5.50^{b} \\
( \pm 1.73)\end{array}$ & $\begin{array}{l}26.50 \\
( \pm 7.39)\end{array}$ & $\begin{array}{l}1.06^{\mathrm{b}} \\
( \pm 0.29)\end{array}$ & $\begin{array}{l}0.50^{\mathrm{ab}} \\
( \pm 0.13)\end{array}$ \\
\hline Ballari $(\mathrm{n}=12)$ & 9 & 13 & $\begin{array}{l}3.67^{\mathrm{a}} \\
( \pm 1.23)\end{array}$ & $\begin{array}{l}28.00 \\
( \pm 5.91)\end{array}$ & $\begin{array}{l}0.73^{\mathrm{a}} \\
( \pm 0.23)\end{array}$ & $\begin{array}{l}0.61^{\mathrm{b}} \\
( \pm 0.13)\end{array}$ \\
\hline Koppal $(\mathrm{n}=12)$ & 11 & 20 & $\begin{array}{l}6.17^{\mathrm{b}} \\
( \pm 1.64)\end{array}$ & $\begin{array}{l}31.00 \\
( \pm 9.08)\end{array}$ & $\begin{array}{l}1.08^{\mathrm{b}} \\
( \pm 0.36)\end{array}$ & $\begin{array}{l}0.51^{\mathrm{ab}} \\
( \pm 0.17)\end{array}$ \\
\hline $\mathrm{F}$ test $(\mathrm{P})$ & & & $<0.05$ & $0.716^{\mathrm{NS}}$ & $<0.05$ & $0.068^{\mathrm{NS}}$ \\
\hline Average $(\mathrm{N}=72)^{*}$ & 15 & 27 & $\begin{array}{l}5.35 \\
( \pm 1.64)\end{array}$ & $\begin{array}{l}28.57 \\
( \pm 8.63)\end{array}$ & 1.44 & 0.48 \\
\hline
\end{tabular}

$\mathrm{H}=$ Shannon's index, $\lambda=$ Simpson index, values in the parentheses indicates the standard deviation

${ }^{\mathrm{a}-\mathrm{b}}$ Values within the column with same letter are not significantly different at $\mathrm{p}<0.05$.

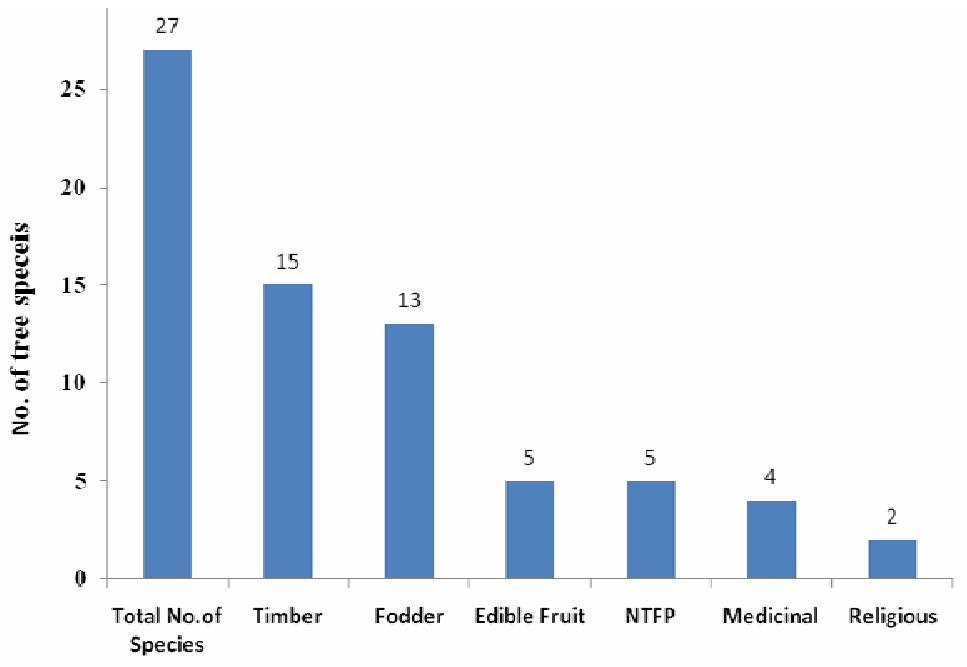

Fig. 2. Usage of tree species by the farmers.

The contrasting result, however, was noticed in Bidar district which is though located at higher elevation but had lower number of species (11) and yet had higher tree density per hectare (29.58) (Table 3). Poor socioeconomic/education background might be the main reason for lower species composition, while higher tree density could be attributed higher rainfall and elevation which favour tree growth. Thus, apart from elevation other factors such as type of farmer, 
preference of the farmer and kind of agroforestry system will affect the species richness and density.

In the present study usage value of tree species was assessed by considering the major usage of the species as expressed by the farmers. The study revealed that 55.56 percentage of the total number species were used for the timber value followed by fodder $(48.15 \%)$ and least was for medicinal and religious value (14.52 and7.41\%, respectively) whereas edible fruit and NTFP were 18.52 per cent each. This emphasizes that farmers were more interested in economic value and other basic needs like food and fodder and were least concerned with medicinal and religious value. It might be due to change in the living style of the farm family and loss of tradition of using ethnic medicines. The results are in line with the Luke et al. (2011) who also found that majority of the farmers valued the tree species for the timber value followed by the fruit and medicinal value and some species were valued for the shade, soil fertility improvement. Quinsavi and Sokpon (2008) assessed the biodiversity in traditional based agroforestry systems in Benin and reported that 69.2 per cent of respondent protected trees for fuel wood followed by 13.8 per cent for timber value, 10.8 per cent for selling of fruit, 3.1 per cent each for medicinal and other uses. They also were of opinion that the species protection on the farm differed according to their utility to farmers and their availability in the region.

\section{References}

Acharya KP 2006. Linking trees on farms with biodiversity conservation in subsistence farming systems in Nepal. Biodivers and Conserv. 15: 631-646.

Atta-Krah, K, Kindt R, SkiltonJN and Amaral W 2004.Managing biological and genetic diversity in tropical agroforestry. Agroforestry Systems 61: 183-194.

Bucagu C, Vanlauwe B, Van Wijk MT and Giller KE 2013. Assessing farmer's interest in agroforestry in two contrasting agro-ecological zones of Rwanda. Agroforestry Systems 87: 141-158.

Chittapur BM and Patil DK 2017. Ecosystem services rendered by tree based land use systems. Indian Journal of Agricultural Science 87(11): 1419-29.

Chittapur BM, Doddabasawa and Umesh MR 2017. On-farm crop diversity for sustainability and resilience in farming. Agricultural Research Communication Centre 38(3):191-200.

Christine O and Nestor S 2008. Traditional agroforestry systems as tools for conservation B of genetic resources of Milicia excelsa Welw. C.C. Bergin Benin. Agroforestry Systems 74: 17-26.

Dhakal A, Cockfield G and Maraseni TN 2012. Evolution of agroforestry-based farming system: a case study of Dhanusha district in Nepal. Agroforestry Systems 86: 17-33.

Luke CNA, Joseph C, Fergus LS and Morag AM 2011. The effect of land use systems on tree diversity: farmer preference and species composition of cocoa-based agroecosy stems in Ghan. Agroforestry Systems 81: 249-265

McNeely JA and Schroth G 2006. Agroforestry and biodiversity conservation- traditional practices, present dynamics and lessons for the future. Biodivers. Conserv. 15: 549-554.

Nair PKR 1985. Classification of agroforestry systems. Agroforestry Systems 3: 97-128.

Nair 2011. Agroforestry systems and environmental quality: Introduction. J. Environ. Quality 40: 784-790

Nair PKR, Gordon AM and Mosquera-Losada MR 2008. Agroforestry. In: Jorgenson SE, Fath BD (eds) Ecological engineering: encyclopedia of ecology, vol 1, Elsevier, Oxford. pp. 101-110.

Nerlich K, Graeff-Honninger S and Claupein W 2013. Agroforestry in Europe: A review of the disappearance of traditional systems and development of modern agroforestry practices, with emphasis on experiences in Germany. Agroforestry Systems 87(2): 475-492.

Ouinsavi C and Sokpon N 2008. Traditional agroforestry systems as tools for conservationof genetic resources of Milicia excelsa Welw. C.C. Bergin Benin. Agroforestry Systems. 74: 17-26 
Quinsavi C,Sokpon N and Bada SO 2005. Utilization and traditional strategies of in-situ conservation of iroko (Milicia excelsa Welw. C.C. Berg.) in Benin. For.Ecol. Manag. 207: 341-350.

Schroth G, da Fonseca GAB, Harvey CA, Gascon C, Vasconcelos HL and Izac A-MN 2004. Agroforestry and biodiversity conservation in tropical landscapes. Island Press, Washington, DC. 1-15

Vodouhe G, Fifanou, Coulibaly O, Gauthier and Sinsin 2011.Traditional agroforestry systems and biodiversity conservation in Benin (West Africa). Agroforestry Systems 82: 1-13.

(Manuscript received on 17 May, 2018; revised on 22 June, 2018) 